\title{
Feeling of Psychological Security at a Sample of Adolescents in Jordan
}

\author{
Ibrahim Bajes Maali ${ }^{1}$ \\ ${ }^{1}$ The World Islamic Sciences \& Education University \\ Correspondence: Ibrahim Bajes Maali.
}

Received: December 28, 2017

Accepted: March 16, 2018

Online Published: April 19, 2018

doi:10.5539/ass.v14n5p104

URL: https://doi.org/10.5539/ass.v14n5p104

\begin{abstract}
This study aims at recognizing the effect of parents' role in feeling of psychological security at a sample of adolescents in Jordan. The sample of study consisted of (450) male and female adolescents, their ages range from (13-18), the individuals of the sample were classified into two groups; the dictator parental role group and the democratic parental role group. Results indicated that the group of democratic parental role have a higher feeling of psychological security and females are more feeling of security than males of the dictator parental role group, and no effect of a housing real did not appear on the feeling of psychological security between both groups.
\end{abstract}

Keywords: parental role, feeling of psychological security

\section{Introduction}

Jounson (2013) assures that the most prominent and important needs is the need to feeling of security \& tranquility, where it is considered a basic factor included by all forms of behavior. individual's need is so much he usually feels with psychological security.

The need to security covers the bodily, and psychological needs, and avoiding pain. And when the individual is able to be so much billed up with security, he seeks to achieve higher needs in the hierarchical succession of needs, like the need to estimate oneself and achieving it (Maslow, 1970).

Al-Dusoogi (2015) indicates that the first thing children need from the psychological part is feeling with the sentimental security, and those who do stuff that are both parents. And Al-Rihami (2004) indicates that in building personality, it is better to concentrate on the prevailing psychological climate in the family towards the adolescent, evident by the way parents accept their children and the way by which they both behave towards them.

Al-Rifa' (2016) assures that parents' role for their children occupies an important position in consisting the sons' personality and techniques of their adaptation, where plenty of effects of that treatment remain in them to newly appear in their treatment of their children in the future. psychological atmosphere of the family is considered one of the important factors in bulding the sons' personality and his techniques of adaptation. The comprehensive warm love with which the individual comforts increases in the amount of self-trust and tranquility towards conditions of life and his ability to confront hard circumstances. But sentiments of alienation and avoidance of parents charge the individual with forms of unhappiness and tragedies and pushes him to constitute a dark outlook towards the community and the family. Nonexistence of security among adolescents was often connected tightly with the weakness of the psychological atmosphere in the family, also connection was found strong between the aggressive behavior and decrease of love and sympathy of parents' sentiment.

Zahran (2011) assures that it is of the basic duties of the parents saving psychological security for children that is considered from the basic requirements of the psychological health to have the personality of paternal role.

But Scars (2014) assures that the paternal role determines what the individual will do or what he can do to obtain stuffing and satisfaction. Thereupon the parents' role is that that consists and grows the adolescent's personality and performs a role in upbringing and forming its behavior, values and its interests. Of course parents' role differs from one family to another, for some fathers are characterized with tolerance, and other some are characterized with domination. In reality the difference of the parents' role leads to existence of different patterns in personality, for the special treatment with which the parents treat their sons has the greatest effect in developing their personality and forming the patterns of their behavior in the future. 
Herlook (2009) indicates to significance of steadfastness in the parents' role in education, where we find that the adolescent is exposed to a certain technique in a certain stand meanwhile he is treated by another technique completely different in a similar stand, the thing that makes the child bewildered and the behavioral standards are mixed to him, accepted or non-accepted to his parents. This type of unsteadfastness in the parental role leads to bad adaptation. Studies indicated that adolescents who are exposed to unsteadfastness of parental role, feel inefficiency and weakness of self-confidance, meanwhile children, who are exposed to steadfastness in the parental role are developing the feelings of ability and self -confidance and show social and adaptation.

The parental role is defined as the process by which the individual is directed to lead the way of his family life and the greater social groups to which he should belong (Al-Ashwal, 2014).

\subsection{Significance of Study}

Appears through the present study sharing by new information about the subject of psychological security by the parental role, it is mentioned that kissing the child within the family that may satisfy his need to feel of security and may make him grow a good adolescent, meanwhile rejecting the child and neglecting him and unsatisfying the need of security will lead to developing the basic anxiety at him (Hall \& Lindz, 2001).

\subsection{Problem of Study}

The study aimed at recognizing the effect of the parental role in feeling of security amongst adolescents of those whom their ages amount between $(13 \& 18)$ years. Exactly the study attempted answering the following question: What is the effect of parenting on Jordanian adolescents sense of security in Jordan?

\subsection{Conceptual and Procedural Definitions}

1. Feeling of security: it is the psychological and personal tranquility.it is the individual's feeling of satisfying the needs (Zahran, 2011). And procedurally defined as the degree obtained by the examinee on the scale of feeling with the psychological security used in this study.

a. Parental role: it is parents' behavior in breeding and directing their children as perceived and expressed between both family upbringing; the democratic family upbringing and the dictatorial (Al-Rihami, 2004). And procedurally defined as the degree obtained by the examinee on the scale of the parental role used in this study.

2. Origin place it means here the environment in which the adolescent was bred, and spent most of his life years, here he distinguishes between two types, they are: the rural environments, they are the villages and the far municipalities from primacy cities, in which the agricultural and nomadic pattern of life prevail, then the urban environment; they are the big cities in which the pattern of commercial, industrial life and aspects of urban civilization prevail (Al-Ashwal, 2014).

\subsection{Hypotheses of Study}

1. There are differences in the level of feeling of security amongst adolescents who were brought up at a paternal role from a democratic pattern about the level of feeling with security amongst adolescents who were bred in a dictatorial pattern .

2. There are no differences in the level of feeling with security at males about it at females.

3. There are no differences in the level of feeling of security at adolescents who were raised at an urban environment than at adolescents who were bred at a rural environment.

4. There are no differences in the effect of interaction to factors of parental role, sex of adolescent, and his origin place in the level of his feeling with security.

\subsection{Previous Studies}

In (Newman, 2008) study to two groups of adolescents it was found that adolescents who enjoy a high trust in self and independence in decision making came from homes, in which the parents' role is characterized with tolerance and democracy of those who provide their sons with explanation and clearance, and that adolescents, who are characterized with dependence and weakness of self-trust came from families parents' role is characterized with domination and dictatorship and few of interaction with their sons.

But Mosen (2011) did a study on a sample of adolescents to uncover the relationship between parents' acceptance of their children or unacceptance, and sons' adaptation and inclination to adaptation with them. Results of study showed that adolescents who did not obtain love and enough acceptance from their parents were less in inclination to adaptation with their parents, and less feeling with security, and self-trust, and less adopted in their social relations. Also they were more with tension than sons, who obtained love and enough acceptance. 
Watson (2010) did a study on a sample of student their parents are characterized with strict system in treatment, and another sample, their parents are tolerant, that is on purpose of disclosing the relationship between the parents and the personality of sons. Results of his study showed the existence of differences among students on scales of self- control, self- security, happiness, anxiety and sentimental maturity.

Zeidan (2014) prepared a study on a sample consists of (138) university students to disclose the relationship between the parents' role and the Ego at sons using a scale of parents' behavior. Results of his study indicated that sentimental coldness at parents leads sons towards depression, feelings o sin and seclusion, and parents' tolerance assists on sons' good adaptation, and the nontolerance leads to anxiety, and the severity at parents leads to the weakness of the Ego at sons and their bad adaptation.

Duriez, Sonenens and Vansteenkiste (2016) did prepare a study aimed at recognizing sharing parents' encouragement in building the objective and dimensions of the family treatment pattern. The sample of study consisted of (956) students of the secondary stage. Results indicated that the democratic technique did not connect with each of trend towards the social domination, but the pattern of dictatorial treatment and connected directly at the level of social domination.

Lopez (2010) wrote a study aimed at disclosing the parental treatment positively or negatively with the behavior of rebellion at students of the secondary stage. The study consisted of (349) students. Results of study indicated that there is a positive connective relationship between the behavior of democratic upbringing pattern and between the good social behavior. Also results of study pointed that the pattern of dominating upbringing shared in students' developing of rebellion, mutiny and violence behavior.

\section{Method and Procedures}

\subsection{Community of Study and the Sample}

The community of study consisted of all students of the secondary stage, but the sample of study amounted to (450) male and female students, were chosen with the technique of random sample. And after application of parental role test on individuals of the sample. Table 1 clears the distribution of the sample individuals on the factors of sex, origin place and the family parental role.

Table 1. Distribution of the sample individuals on factors of sex, origin place, and the family parental role

\begin{tabular}{cccccc}
\hline & \multirow{2}{*}{ Origin place } & \multicolumn{3}{c}{ Sex } & \multirow{2}{*}{ Total } \\
\cline { 3 - 4 } & & Males & Females & \\
\hline \multirow{3}{*}{ Pattern of upbringing } & \multirow{2}{*}{ Dictatorial } & Rural area & 28 & 18 & \multirow{2}{*}{226} \\
& & Urban & 113 & 67 & \\
& \multirow{2}{*}{ Democratic } & Rural area & 26 & 119 & \\
& & Urban & 79 & 100 & 227 \\
& & & 246 & 2204 & 450 \\
\hline
\end{tabular}

\subsection{Instruments of Study}

\subsubsection{Scale of Parental Role}

The parental role test, prepared by the researcher was used. And the democratic parental role consists of four dimensions: 1. Parents understanding. 2. Parents' respecting and appreciation. 3. Parents' Sacrifice. 4. Parents' role as friends.

But the dictatorial parental role consists of four dimensions, they are: 1.Dominattion and rejection. 2. Negligence and prevention. 3. Psychological and bodily punishment. 4. Differentiation between brothers and sisters.

The test consisted of (56) items representing the dimensions or the previous eight trends enlisted on the scale of (4) degrees represent the extent of behavior repetition. And logical validity had been extracted for the scale by refuging to the technique of arbitration of specialists in psychology and counseling to judge the validity of each item in the dimension scale laid to measure it. Reliability coefficient had been extracted by the half method after applying it on a sample of the secondary stage students, for the reliability coefficient was (.83).

\subsubsection{Maslo-test for Feeling of Security}

Maslo-test for feeling of the inflective security was used. The test consists of (75) items represent three groups, each group covers (25) items. The examinee answers about the test, either with yes or No or uncertain. Thus, the 
degree that can be obtained by the examinee amounts between (zero \& 75), where the lower degrees indicate to not fleeing with security, meanwhile the highest degrees indicate to feeling of security. And the test enjoys correlative logical coefficient amounting to (0.64), and the reliability test coefficient had amounted to $(0.84)$ in behalf of the re-test technique, meanwhile amounted to $(0.86)$ by using the half method.

\subsubsection{Designing and Statistical Analysis}

This is a connective study aimed at recognizing the effect of independent factors, sex and origin place (urban, rural), the dictatorial \& democratic parental role in the subordinate variable, and it is the feeling with security amongst adolescents. The study used the method of the Tripartite variation analysis with the design $2 \times 2 \times 2$. Also used the method of MANCOVA (analysis of multiple covariance).

\section{Results}

This study aimed at recognizing the effect of parental role, sex, and origin place of feeling with security amongst adolescents. Results of variation analysis in Table 2 indicate to existence of differences with statistical significance between averages of the dictatorial parental role group degrees and individuals of the democratic parental role group on the test of feeling with security. And the value of (F) had been (198.33) with degrees of freedom (4491), and it is a value with statistical significance $(\mathrm{P}<0001)$. But average of degrees of examinees from both groups on the test of feeling with security, it had been (40.84) for the dictatorial group and (27.26) for the democratic group. These average appear in the Table 3. when the low degrees were on the test indicate to non-feeling with security, and the high degrees indicate to feeling of security, this results means that the level of feeling with security at individuals of the democratic group higher than it at individuals of the dictatorial group, and it is a result supports the first hypothesis of this study.

Table 2. Average of degrees of the dictatorial parental role group individuals and individuals of the democratic parental role group on the test of feeling with security.

\begin{tabular}{ccccc}
\hline Source of Variation & Total of Squares & Degrees of Freedom & Average of Squares & F. Value \\
\hline Sex & 403.93 & 1 & 403.92 & $* 4.140$ \\
Origin place & 337.22 & 1 & 337.22 & 3.45 \\
Parental role & 19368.887 & 1 & 19368.887 & $* * 198.33$ \\
Sex x origin place & 18.657 & 1 & 18.657 & 0.191 \\
Sex x the parental role & 2.178 & 1 & 2.178 & 0.022 \\
Origin place x the parental role & 183.280 & 1 & 183.280 & 1.877 \\
Sex x origin place x the parental role & 6.193 & 1 & 6.193 & 0.063 \\
Error & 43164.754 & 442 & 97.658 & \\
Total & 64813.121 & 449 & 144.350 & \\
\hline
\end{tabular}

Table 3. Average of examines on the test of feeling with security in light of both factors: origin place and the parental role

\begin{tabular}{cccc}
\hline Origin place & Rural Area & Urban Area & Average \\
\hline Dictatorial & 37.76 & 41.60 & 40.84 \\
Democratic & 27.00 & 27.33 & 27.26 \\
Average & 32.49 & 3.48 & \\
\hline
\end{tabular}

Also the results of variation analysis that appear in the Table 2 indicate to the existence of differences with statistical significance between averages of males and females on the test of feeling with security where the value of (F.) was (4.14) with degrees of freedom (449.1): that it is a value with statistical significance $(\mathrm{P} \leq 05)$. These differences were for the interest of females, where the average of their degrees was (31.94), meanwhile the average of males' degrees was (35.86) as shown in the Table 4. This result disagrees with the second hypothesis of this study.

But what is related to the factor of origin place, the results of variation analysis (Table 2) also indicates that there was no effect with statistical significance for this factor on the feeling with security, or there are no differences 
exist with statistical significance between both averages of adolescents, who were brought up at a rural environment and those brought up at an urban environment, where the average of the rural area sons was (32.49) and sons of the urban area was (34.48) (Table 3). And this result supports the third hypothesis.

Table 4. Examinees' averages on the test of feeling with security in light of both factors: sex and parental role

\begin{tabular}{cccc}
\hline Sex Parental Role & Males & Females & Average \\
\hline Dictatorial & 41.61 & 39.56 & 40.84 \\
Democratic & 28.14 & 26.49 & 27.26 \\
Average & 35.86 & 31.94 & \\
\hline
\end{tabular}

And what relates with the effect of interaction among independent variables in this study on feeling with security the results of analyzing variation (Table 2) indicate that effect with statistical significance did not exist for interaction among independent factors in the feeling with security. it is a result that supports the fourth hypothesis.

And the (Table 5) shows the simple and multiple and increases in the square of correlation coefficients between feeling with security from one part and variables of sex, origin place, family parental role, and interactions in between from other part.

Table 5. Simple, multiple and increases of correlation coefficients in the square of correlation coefficient among the subordinate variables, independent variables and interactions in between

\begin{tabular}{ccccc}
\hline Variation & $\begin{array}{c}\text { Simple } \\
\text { Correlation R } \\
\text { Coefficient }\end{array}$ & $\begin{array}{c}\text { Multiple } \\
\text { Correlation } \\
\text { Coefficient } \mathrm{R}\end{array}$ & $\begin{array}{c}\text { Square of } \\
\text { Correlation } \\
\text { Coefficient } \mathrm{R}^{2}\end{array}$ & $\begin{array}{c}\text { Increase in Square } \\
\text { of Correlation } \\
\text { Coefficient }\end{array}$ \\
\hline Sex & 0.163 & 0.16283 & 0.02651 & 0.02651 \\
Origin place & 0.0666 & 0.17902 & 0.03205 & 0.00553 \\
Parental role & 0.723 & 0.7255 & 0.526 & 0.49438 \\
Sex x origin place & 0.171 & 0.72559 & 0.52647 & 0.00005 \\
Sex x parental role & 0.025 & 0.72674 & 0.52674 & 0.00027 \\
Origin place x the parental role & 0.169 & 0.72973 & 0.53251 & 0.00577 \\
Sex x origin place x parental role & 0.061 & 0.72976 & 0.53255 & 0.00004 \\
\hline
\end{tabular}

Table 5 shows that variable of sex had explained (\%2.6) from variation in feeling with security. And when origin place was added to the variable of sex, both of them explained (\%.3.2) from variation in feeling with security that is with an increase amounts to (\% 0.5) approximately. When the pattern of parental role was added to both previous variables, the three variables altogether explained what amounts to $(\% 52.6)$ from the variation in feeling with security, that is by an increase amount to (\% 49.4).

And the Table 6 shows the results of variation analysis is (MANCOVA) feeling with security on variables of sex, origin place and the parental role without inserting interactions in between. And it is clear from the Table 6 that part of variation explained by these three variables .. it is with statistical significance on the level of significance (0.0001).

The Table 7 shows results of variation analysis MANCOVA of feeling with security on variables of sex, origin place and the parental role and the interactions in between.

Table 6. Results of variation analysis for declination of the subordinate variable (feeling with security) on variables of the study

\begin{tabular}{cccccc}
\hline $\begin{array}{c}\text { Source of } \\
\text { Variation }\end{array}$ & $\begin{array}{c}\text { Degrees of } \\
\text { Freedom }\end{array}$ & $\begin{array}{c}\text { Total of } \\
\text { Squares }\end{array}$ & $\begin{array}{c}\text { Average of } \\
\text { Squares }\end{array}$ & $\begin{array}{c}\text { F. } \\
\text { Value }\end{array}$ & $\begin{array}{c}\text { Level of } \\
\text { Significance }\end{array}$ \\
\hline Declination & 3 & 34119.92 & 1137.30 & 165.26 & 0.0001 \\
Error & 446 & 30694.04 & 68.82 & & \\
\hline
\end{tabular}


It is noticed from the Table 7 that these three variables and interactions in between shares, in general, in explaining the rate of $(\% 53.2)$ from variation in feeling with security.. it is with statistical significance on the level (0.0001).

Table 7. Results of variation analysis MANCOVA of the subordinate variable (feeling with security) on variables of study and interactions in between

\begin{tabular}{cccccc}
\hline $\begin{array}{c}\text { Source of } \\
\text { Variation }\end{array}$ & $\begin{array}{c}\text { Degrees of } \\
\text { Freedom }\end{array}$ & $\begin{array}{c}\text { Total of } \\
\text { Squares }\end{array}$ & $\begin{array}{c}\text { Average of } \\
\text { Squares }\end{array}$ & $\begin{array}{c}\text { F. } \\
\text { Value }\end{array}$ & $\begin{array}{c}\text { Level of } \\
\text { Significance }\end{array}$ \\
\hline $\begin{array}{c}\text { Declination } \\
\text { Error }\end{array}$ & 7 & 34516.47661 & 4930.92523 & 71.93565 & $0.0001>$ \\
\hline
\end{tabular}

\section{Discussion}

The study concerned about recognizing the effect of the parental role in feeling of adolescents with the security and with what was the effect of parental role in feeling with security differs by difference of sex of adolescent and place of his origin. But results of this study had shown existence of effect with statistical significance for the parental role. Also results of multiple declination analysis that the parental role variable had shared alone after stabilizing both variables of sex and origin place, with what is not less than $(9 \%)$ from variation in feeling with security at the individual of the study. And when added to both variables of sex and origin place appeared that the rate what is explained by the variable of sex alone (\%2.6) and the rate of increase added by the variable of origin place is $(\% 0.05)$ to become both variables of sex and origin place altogether.

Thus results evidently showed the effects of parently role in adolescents' feeling with security. It was evident from those results that adolescents, who were -broughtup at a family environment characterized with dictatorial pattern incline into non-feeling with security meaning that they suffer very much of anxiety, meanwhile adolescents who were broughtup at a family environment characterized with democracy and understanding incline to feeling security meaning that they are less anxious and more tranquil. Of course this results with what was meant by numerous of previous studies, like Duriez (2015), Lopez (2015) and Zeidan (2014) study that indicated, in general, to technique of dictatorial parental treatment that is characterized with severity, punishment, and rejection connects with sons' feeling with anxiety, threat, and non-security, also connects with bad adaptation and lowness of level of their self-trust at a negative from reflected on their psychological health. But the democratic role of parents characterized with understanding, sympathy, love, acceptance and respect of feelings, it connects feeling with security, tranquility, rise of trust level and good adaptation at a form positively reflected on the individual's psychological health. Really the result of this study and results of previous studies too in what is related with the effect of parents' role in feeling with security, but assures the significance of family role in growth and development of the personality of the child and its psychological health, especially in what is related with the parents' technique and the sons and their upbringing.

But what relates to the variable of sex, the results indicated to existence of differences with statistical significance between males and females for the interest of females, where the level of feeling with security at females seemed higher than it at males. Really such this result can be understood in light of relationship performed in our community between the family from one part and its male sons, or females from another part. That is most of families in our community tend to grant freedom and independence and depending on oneself for its sons, meanwhile tend to protecting females, caretaking on them and belittling responsibility on them, the thing that let them feel with security and tranquility more than males.

And what relates with the variable of origin place, results of this study did not show differences in the level of feeling with security refer to this variable. Perhaps that is understood that urbanization did not affect in changing the parents' role about what is spread in rural area. Anyway, this thing is in need of more investigation and study. Thus, the most important that can be deduced from this study is assuring the parents' role in education through techniques of counseling and instruction, especially family counseling that assures parents' role in developing the personality of their children and reflections of techniques of their breeding and upbringing on their feeling with security or non-security and on their personal and social good adaptation, and so on their psychological health in general.

And finally, results of this study that showed the independent variables tackled by the study had explained the rate of $(\% 52.6)$ leads to the necessity of aiming at searching for other variables to explain what remained of variation in feeling with security amongst adolescents. And from the factors that the researcher 
recommends......to study its impact in feeling with security are the factors of family cohesiveness, the social and economic level of the family, size of the family and the birth order of the adolescent.

\section{References}

Al-Ashwal, A. (2014). The Personality Psychology. Englo-Egyptian Library, Cairo.

Al-Dusoogi, K. (2015). Educational Growth of the Child and Adolescent, Dar Al-Nahdah Al-A'rabiyah. (Arab Renaissance House), Cairo.

Al-Rifai', N. (2016). Psychological Health. Amman, Jordan.

Al-Rihani, S. (2004). Mental Retardation. Jordan.

Duriez, B., Soenens B., \& Vansteenkiste, M. (2016). The Relative contribution of Parental Goal Promotion and Parenting Style Dimesions. European Journal of Personality, 21, 507-527.

Hall and Lindzy (2001). Theories of Personality, John Wily.

Hurlock, E. B. Child Development (p. 452). McGraw Hill book company, N.Y.

Johnson. (2013). Pupil, Personal and Guidance Services (p. 219). McGraw-Hill, N.Y.

Lopez, M. (2016). Prevention of Teenage Defiant Behaviors: Parenting Style as Protection Factors. International Journal of Psychology \& Psychological Therapy, 8(1), 73-84.

Maslow, A. (1970). Motivation and Personality (2nd ed., p. 37). Harper and Row, Publishers, Inc. N.Y.

Mussen, P. (2011). The Influence of Father-Son Relationships and Adolescent Personality and Attitudes. J. of Child Psychology, and Psychiatry, 4, 3-16.

Newman, B. (2008). An Introduction to the Psychology of Adolescence (p. 229). The Dorsey Press.

Scars, R. (2014). Patterns of Child Rearing (p. 243). Raw, Paterson and Company, N.Y.

Watson, G. (2010). Some Personality Differences in Children Related to Strict or Permissive Parental Discipline, J. of Social Psychology, 4, 227-229.

Zahran, H. (2011). (Childhood and Adolescence) Psychology, A'lam Al-Kotob (World of Books), Cairo.

Zeidan, M. (2014). Students' Personality Trait at Universities and their Relationship with Parents' Care, Damascus.

\section{Copyrights}

Copyright for this article is retained by the author(s), with first publication rights granted to the journal.

This is an open-access article distributed under the terms and conditions of the Creative Commons Attribution license (http://creativecommons.org/licenses/by/4.0/). 